\title{
Effects of plant population and nitrogen fertilizer on yield and efficiency of maize-bean intercropping ${ }^{(1)}$
}

\author{
Luiz Balbino Morgado ${ }^{(2)}$ and Robert William Willey ${ }^{(3)}$
}

\begin{abstract}
Nitrogen supply and plant population are basic parameters for cereal-legume intercropping. In order to study plant population and nitrogen fertilizer effects on yield and yield efficiency of maizebean intercropping, a field experiment was established. Three bean plant populations and three nitrogen levels were used. Maize dry matter accumulation decreased with increases in bean plant population. Competitive effect of intercrop beans on maize yields was high at higher plant populations, being decreased by nitrogen fertilizer; application of $50 \mathrm{~kg} \mathrm{ha}^{-1} \mathrm{~N}$ was very efficient in increasing maize cob yield. Intercropping significantly decreased harvest index of beans in all plant population and nitrogen fertilizer situations. The efficiency of intercropping, compared to sole cropping, was evidenced by the values obtained for Land Equivalent Ratio (LER) for biomass, cob and pod yields that increased with increases in bean plant populations and nitrogen fertilizer levels.
\end{abstract}

Index terms: Zea mays, Phaseolus vulgaris, mixed cropping, land use.

\section{Efeito de população de plantas e adubação nitrogenada na produção e eficiência} do consórcio milho-feijão

\begin{abstract}
Resumo - A disponibilidade de nitrogênio e a população de plantas são parâmetros básicos para o consórcio de gramíneas e leguminosas. Os efeitos de diferentes populações de plantas de feijão e níveis de nitrogênio na produção e eficiência do consórcio milho-feijão foram estudados em um experimento de campo. Foram usadas três populações de plantas de feijão e três níveis de nitrogênio. $\mathrm{O}$ acúmulo de matéria seca do milho durante o ciclo vegetativo decresceu à proporção que a população de feijão aumentou. $\mathrm{O}$ efeito competitivo do feijão na produção do milho consorciado, que se mostrou maior nas maiores populações de plantas, foi atenuado pela aplicação da adubação nitrogenada; a aplicação de $50 \mathrm{~kg} \mathrm{ha}^{-1}$ de $\mathrm{N}$ foi muito eficiente no aumento da produção de espiga do milho. O consórcio diminuiu significativamente o índice de colheita do feijão em todas as populações de plantas e em todos os níveis de nitrogênio aplicados. A eficiência do consórcio, em comparação ao plantio isolado das culturas, foi comprovada por meio dos valores do índice Uso Eficiente da Terra (UET) correspondentes às produções de espiga, vagem e biomassa, que aumentaram com os incrementos tanto da população de plantas de feijão como dos níveis de nitrogênio.
\end{abstract}

Termos para indexação: Zea mays, Phaseolus vulgaris, cultivo consorciado, uso da terra.

\section{Introduction}

A general assumption in intercropping cereals with legume crops is that the legume, when associated

\footnotetext{
(1) Accepted for publication on July 31, 2003.

(2) Embrapa-Centro de Pesquisa Agropecuária do Trópico SemiÁrido, Caixa Postal 23, CEP 56300-970 Petrolina, PE. E-mail: lmorgado@cpatsa.embrapa.br

(3)University of East Anglia, School of Development Studies, NR4 7TJ Norwich, United Kingdom. E-mail: r.willey@uea.ac.uk
}

with the specific Rhizobium, may have most of its $\mathrm{N}$ need supplied through fixation of atmospheric $\mathrm{N}$, leaving the soil available $\mathrm{N}$ for the companion cereal.

There is evidence that leguminous plants can benefit the intercrop cereals in the same season through $\mathrm{N}$ excretion (Eaglesham et al., 1981) and nodule decomposition (Saito, 1982; Bonetti, 1991). There is marked variation in the $\mathrm{N}$ supplying ability among legume species (Senaratne et al., 1995).

Competition between component crops for growth-limiting factors is regulated by morphophysiological differences and agronomic 
factors such as the proportion of crops in the mixture and fertilizer application (Trenbath, 1976; Russell \& Caldwell, 1989). Intraspecific competition seems to be more intense than interspecific competition (Oljaca et al., 2000).

It has been observed that the roots of intercrops freely intermingle resulting in complementary interactions between the root systems, such as $\mathrm{N}$ transfer or complementary use of different nutrients (Natarajan \& Willey, 1980; Adiku et al., 2001). Studies on $\mathrm{N}$ transfer from forage legumes to grass have demonstrated that transfer occurs over a distance of at least $20 \mathrm{~cm}$, and reaches a maximum when the legume/grass ratio is greater than 1:1 (Brophy et al., 1987).

The efficiency of cereal-legume intercrop systems, expressed as land equivalent ratio (LER), increases, remains unchanged or decreases under application of increasing levels of N fertilizer (Searle et al., 1981; Baker \& Blamey, 1985; Ofori \& Stern, 1986; Pilbeam et al., 1995; Siame et al., 1998).

To study the effect of a $\mathrm{N}$-fixing legume on a companion cereal, the cereal plant population and spacing has to be the same in sole and intercropping systems. The additive model allows investigation of the effect of different bean plant populations on maize and bean intercrops.

As the $\mathrm{N}$ supply and plant population definition are basic parameters for cereal-legume intercropping, this study was conducted to examine the effects of bean plant population and $\mathrm{N}$ fertilizer on dry matter production, yield and efficiency of maize-bean intercrop system.

\section{Material and Methods}

The experiment was carried out in a sandy loam soil with low fertility $\left(0.8 \mathrm{~g} \mathrm{~kg}^{-1} \mathrm{~N}, 0.21 \mathrm{cmol}_{\mathrm{c}} \mathrm{dm}^{-3} \mathrm{~K}\right.$, $3.5 \mathrm{mg} \mathrm{dm}^{-3} \mathrm{P}, 7.0 \mathrm{cmol}_{\mathrm{c}} \mathrm{dm}^{-3} \mathrm{Ca}, 2.4 \mathrm{cmol}_{\mathrm{c}} \mathrm{dm}^{-3} \mathrm{Mg}$ ) and pH 7.6 at John Innes Institute farm, in Norwich, East Anglia region of the United Kingdom (latitude: $52^{\circ} 38^{\prime} \mathrm{N}$, longitude: $1^{\circ} 17^{\prime} \mathrm{E}$, altitude: $37 \mathrm{~m}$ ). The average annual rainfall is $645 \mathrm{~mm}$ with a good distribution pattern. The mean temperature was $10.2^{\circ} \mathrm{C}$ with maximum and minimum of $13.1^{\circ} \mathrm{C}$ and $7.3^{\circ} \mathrm{C}$, respectively.

Three different proportions of a plant population of 240,000 plants ha ${ }^{-1}$, considered as optimum for sole cropped beans, were taken as the intercrop bean plant populations: $25 \%\left(60,000\right.$ plants $\left.\mathrm{ha}^{-1} ; \mathrm{B} 1\right)$,
$50 \%$ (120,000 plants ha $\left.{ }^{-1} ; \mathrm{B} 2\right)$ and 75\% (180,000 plants ha ${ }^{-1}$; B3) and interplanted with maize in an additive model, resulting in three row arrangements: one row of maize for one row of beans (1:1), one row of maize for two rows of beans (1:2) and one row of maize for three rows of beans (1:3). A uniform population of 55,000 plants ha ${ }^{-1}$ and a constant row spacing of $1.20 \mathrm{~m}$ were maintained for maize in both cropping systems, because any variation in intercropped maize, compared with sole cropping, would be attributed to the addition of beans between maize rows. Sole beans were sown on a $0.30 \mathrm{~m}$ row spacing. All plots were $48 \mathrm{~m}^{2}$ $(4.8 \times 10 \mathrm{~m})$.

Three levels of mineral $\mathrm{N}\left(0 \mathrm{~kg} \mathrm{ha}^{-1}, \mathrm{~N} 1 ; 50 \mathrm{~kg} \mathrm{ha}^{-1}, \mathrm{~N} 2\right.$ and $100 \mathrm{~kg} \mathrm{ha}^{-1}, \mathrm{~N} 3$ ) were applied to sole and intercropped maize rows as ammonium nitrate $(34.5 \% \mathrm{~N})$ in two split halves at 26 and 42 days after sowing (DAS).

The experiment was arranged in a split-plot design with three replicates comprising a factorial combination of three bean plant populations (B1, B2, B3) and three $\mathrm{N}$ levels $(\mathrm{N} 1, \mathrm{~N} 2, \mathrm{~N} 3)$ totaling nine intercropping treatments. Bean plant populations were the main plots while $\mathrm{N}$ levels were randomized as subplots within each main plot. There were four additional treatments: three $\mathrm{N}$ levels applied to sole maize (N1, N2, N3) and one Rhizobium inoculation applied to sole beans. The analysis of variance for maize included the sole cropping situation as zero plant population of beans. A probability of $5 \%$ or less $(\mathrm{P}<0.05)$ of significance was considered to differentiate effects among treatments.

Assessment of maize-bean intercropping efficiency relative to sole cropping was estimated by the Land Equivalent Ratio (LER) (Willey, 1985). Calculation of individual LER for maize crop considered yields of sole and intercropping systems at the same $\mathrm{N}$ level. For bean crop, calculation included a single sole cropping without nitrogen.

The experimental area was ploughed and raked by tractor and a basal dose of $\mathrm{P}$ and $\mathrm{K}$, corresponding to $59.3 \mathrm{~kg} \mathrm{ha}^{-1} \mathrm{P}_{2} \mathrm{O}_{5}$ and $59.3 \mathrm{~kg} \mathrm{ha}^{-1} \mathrm{~K}_{2} \mathrm{O}$, was uniformly broadcast before planting. Maize, variety Markant, and beans, variety Canadian Wonder, were planted simultaneously on May 25, maize sown by a tractor drill and beans by hand planter. All the bean seeds were inoculated with specific bacteria (Rhizobium phaseoli) for beans at sowing time. The plots were hand-weeded and there was no incidence of insect or disease in either crop.

Three plants of maize and beans were sampled from middle rows of all plots of two replicates at $48,62,82,92$, 107,127 and $138 \mathrm{DAS}$ and dried at $70^{\circ} \mathrm{C}$ for dry matter determination. The number of nodules on roots of beans was counted every sampling time. At harvest time, one 
meter at each end of all plots was discarded as border. Outside rows of sole and intercropped maize plots were discarded as border and two $5 \mathrm{~m}$ long middle rows were harvested. Four and $5 \mathrm{~m}$ long rows were harvested for sole and intercropped beans, respectively. Six rows were harvested for sole cropped beans. The number of rows harvested in intercropped bean plots was three for B1 and $\mathrm{B} 3$, and four for B2.

Maize was harvested at 138 DAS and plants were cut at soil level and separated into cobs and stover to estimate cob and vegetative yields. Three plants and five cobs of each maize plot from all replicates were dried at $70^{\circ} \mathrm{C}$ for dry matter determination.

Bean pods were harvested three times: 103, 119 and 127 DAS, but yields were pooled and analyzed together because the second and third yields were very low compared with the first one. Pods were counted and weighed at each harvest and a sample of 50 pods of each bean plot from all replicates was dried at $70^{\circ} \mathrm{C}$ to estimate dry matter yield. At the final harvest (127 DAS), a sample of three plants was dried at $70^{\circ} \mathrm{C}$ for dry matter determination.

\section{Results and Discussion}

Dry matter accumulation in intercropped maize was very slow in early stages at all bean populations and all $\mathrm{N}$ levels, and $\mathrm{N}$ effect was similar in all levels until 62 DAS (Figure 1). Dry matter accumulation at B1 was similar in all $\mathrm{N}$ levels until 82 DAS and in $\mathrm{N} 2$ and N3 throughout the growing period except at 92 DAS when there was a drop at N3; at N1, it slowed down after 92 DAS, being less than N2 and N3 from 107 DAS onwards. Plant growth at B2 after 62 DAS was always lowest at N1, and was not consistently different at $\mathrm{N} 2$ and $\mathrm{N} 3$, although at 138 DAS dry matter yield was higher at N2. Similar to B2, plant growth was least in N1 from 62 DAS onwards, and was higher in N2 than at N3 at 102 and 138 DAS. Nitrogen effect on plant growth of sole maize was not definite until 92 DAS. From that time onwards, dry matter accumulation increased slightly with $\mathrm{N}$ applications.

Figure 2 shows the patterns for dry matter accumulation in intercropped bean plants. Trends in dry matter accumulation per plant at B1 were very similar in all $\mathrm{N}$ levels at early stages of growth and patterns did not differ much throughout the season. Nitrogen did not affect dry matter of beans at B2 up to 62 DAS, however, at 127 DAS, it was higher at N1.
At B3, dry matter accumulation was similar at all $\mathrm{N}$ levels up to $82 \mathrm{DAS}$, showing the same trend as B2 at 127 DAS.

Intercropping, as compared with sole cropping, decreased biomass yield of maize at all bean

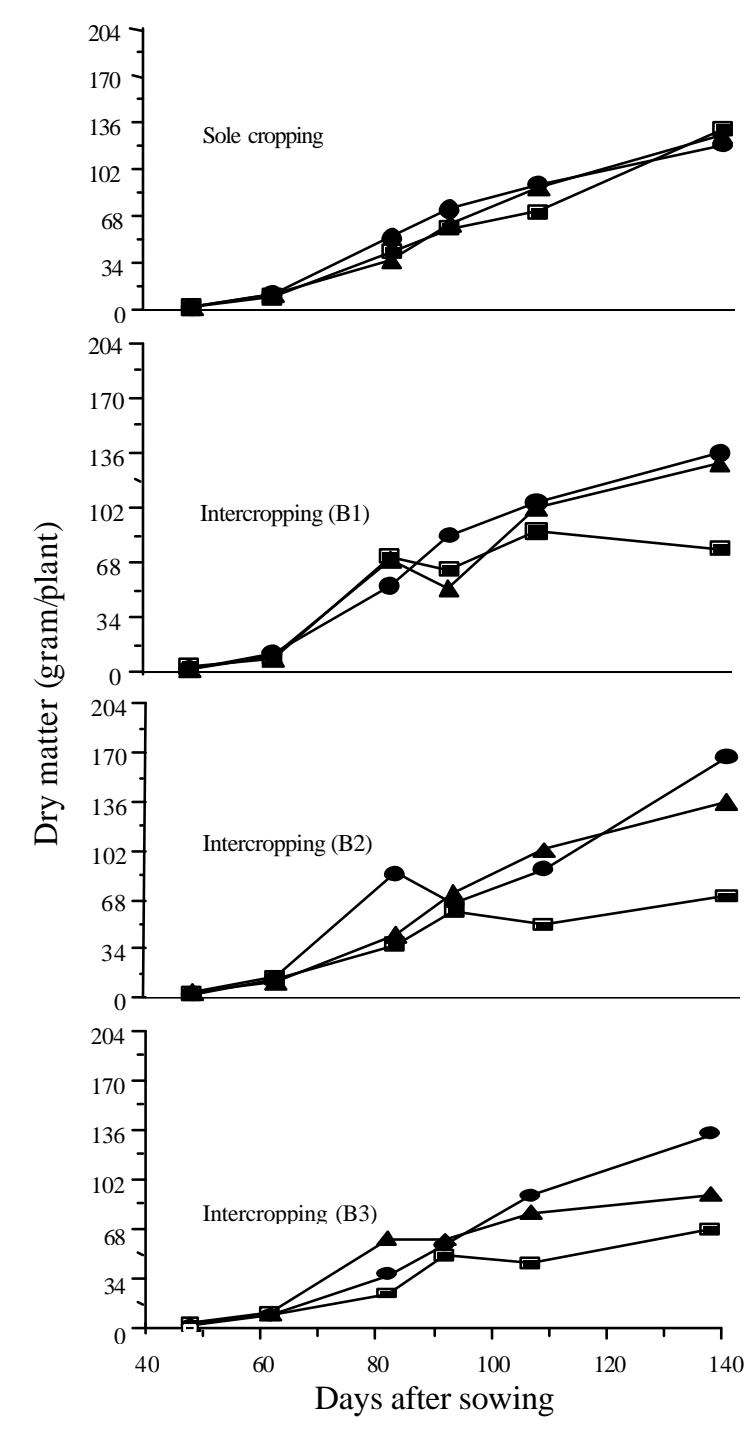

Figure 1. Dry matter accumulation in maize plant, under nitrogen levels of $0(\mathrm{~N} 1, \boldsymbol{\square}), 50(\mathrm{~N} 2, \bullet)$ and $100 \mathrm{~kg} \mathrm{ha}^{-1}$ $(\mathrm{N} 3 \boldsymbol{\Delta})$, as sole cropping and intercropped with beans under population 1 (B1), population 2 (B2) and population 3 (B3). L.S.D. for bean population at 107 DAS $=16.3$; L.S.D. for nitrogen level at $107 \mathrm{DAS}=13.0$; L.S.D. for nitrogen level at $138 \mathrm{DAS}=25.6$. 
populations and all $\mathrm{N}$ levels (Table 1). The biggest decreases were at B3, and the highest at N1 when reductions were $35 \%$ for $\mathrm{B} 1$ and $\mathrm{B} 2$, and $46 \%$ for $\mathrm{B} 3$. Competitive effect of beans in $\mathrm{B} 2$ was similar to $\mathrm{B} 1$; both showed less competition than B3.

Nitrogen increased significantly biomass yield of maize. The highest increases were obtained at N2: $15,47,44$ and $54 \%$ for sole cropping and intercropping at $\mathrm{B} 1, \mathrm{~B} 2$ and $\mathrm{B} 3$, respectively. Intercropping effects decreased in lower bean populations at $\mathrm{N} 3$ and differences from sole cropping results were $14 \%$ and $8 \%$ at $\mathrm{B} 1$ and $\mathrm{B} 2$, respectively. The highest $\mathrm{N}$ level (N3) did not improve biomass yield of intercropped maize at B3 compared to N2. It seems that interspecific competition at the highest bean population was not affected as $\mathrm{N}$ availability in
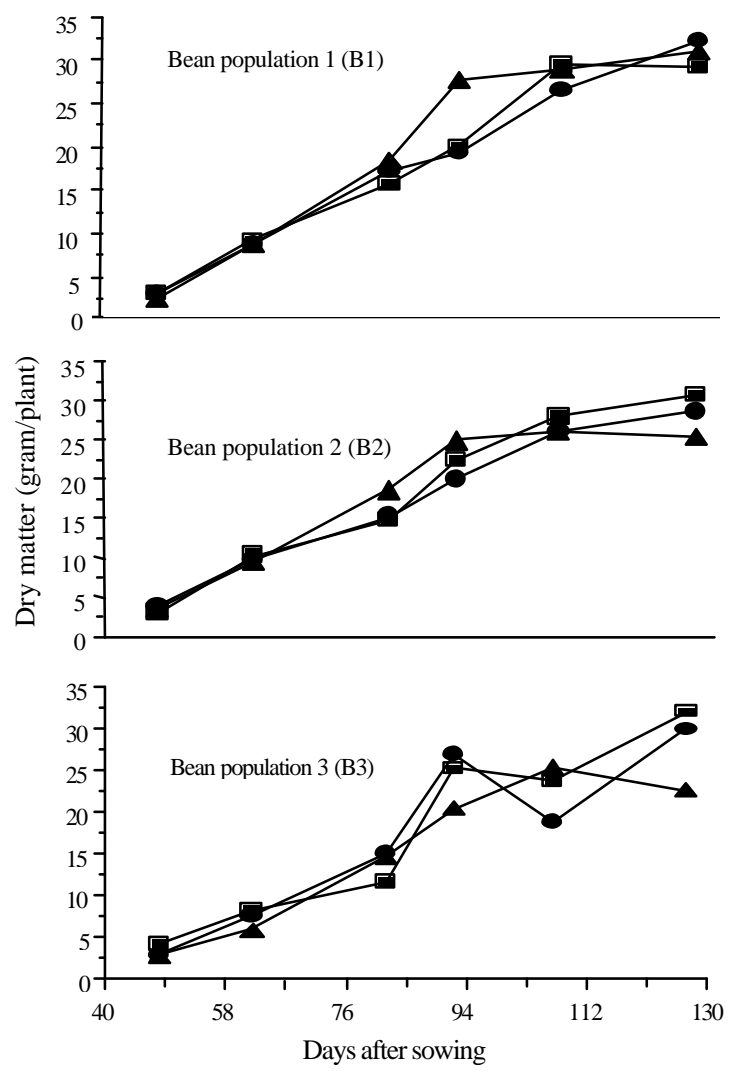

Figure 2. Dry matter accumulation in bean plant, under different plant population (B), intercropped with maize, under nitrogen levels of $0(\mathrm{~N} 1, \boldsymbol{\square}), 50(\mathrm{~N} 2, \bullet)$ and $100 \mathrm{~kg} \mathrm{ha}^{-1}(\mathrm{~N} 3, \mathbf{\Delta})$. the soil increased at N3, which might be an evidence of bean competition for available nitrogen. Biomass yield of sole maize increased slightly with increases in $\mathrm{N}$ levels up to $\mathrm{N} 3$.

Neither bean population nor $\mathrm{N}$ levels significantly affected cob yield. Cob yield was lowest at B3 in all $\mathrm{N}$ levels and the main reason for this was the decrease in number of cobs per plant compared with lower bean populations (B1, B2). Cob yield of sole maize increased slightly by $\mathrm{N}$ application up to $\mathrm{N} 3$.

Harvest index of maize tended to be higher in intercropping than in sole cropping, indicating that the proportion of cob yield in relation to biomass yield was higher in intercropping. There was a tendency for lower harvest index of intercropped maize at N3, suggesting that the proportion of cob yield related to biomass yield decreased at higher $\mathrm{N}$ availability to plants.

Biomass yield of beans increased progressively and significantly as bean populations increased at all $\mathrm{N}$ levels (Table 1). For B1 and B2, there was no consistent change in biomass yield due to increase in $\mathrm{N}$ level, however, at B3 it increased significantly as the $\mathrm{N}$ level increased. It seems that, as bean rows got closer to maize rows at B3, the bean plants benefited from the $\mathrm{N}$ applied to maize rows (Siame et al., 1997).

Intercropping decreased bean biomass yield at all bean populations and all $\mathrm{N}$ levels, as compared to sole cropping system. This effect was lessened as bean population and $\mathrm{N}$ level were increased. Pod yield of beans increased significantly as bean population was increased. Basically the $\mathrm{N}$ applied to maize rows did not affect it at B1 and B2. However, it increased progressively at B3, with each increment in $\mathrm{N}$ level, and weight of individual pod was the main yield component for the increase (Table 2). This effect was also observed in the bean biomass yield. The capacity of bean plants at high population to compete for soil resources was improved by $\mathrm{N}$ application contributing to higher pod and biomass yields.

Pod yield of intercropped beans was very low as compared with sole bean, mainly in low bean population. This effect decreased at B3 with $\mathrm{N}$ application that increased pod yield by $31 \%$ at N3 as compared to N1. Decreasing effect of intercropping 
was also observed in individual pod weight, but again it decreased at B3 by $\mathrm{N}$ application (Table 2). Intercropping significantly decreased harvest index of beans at all bean populations and $\mathrm{N}$ levels except at B1 in N1. There was no real difference between intercropping treatments.

Increasing bean population decreased the number of pods per bean plant significantly and, at B1, it had significantly higher number of pods than sole cropped beans (Table 2). Dry matter per plant of beans at final harvest decreased significantly as bean population increased from B1 to either B2 or B3; this effect was evident in all $\mathrm{N}$ levels. Compared to sole cropping, dry matter was reduced at N1 in B2 and $\mathrm{B} 3$, but it increased at B1 which had a population proportion of $25 \%$ of sole bean population. Presumably the lower bean population at B1 and the lower maize competition due to the greater distance between maize and bean rows provided a better soil resource condition with higher light availability for bean plants. Dry matter was higher at B3 than at B2, and the increase was significant at N3, suggesting that bean plants at B3 could benefit from $\mathrm{N}$ applied to maize at N2 and N3 since they were closer to maize rows.
A significant decreasing effect of bean population on maize biomass Land Equivalent Ratio (LER) was observed only at B3 (Figure 3). As bean population was increased to B3, maize LER decreased in all $\mathrm{N}$ levels with the biggest decrease $(23 \%)$ at N3. This suggests that the $\mathrm{N}$ applied to maize rows stimulated the bean competitive effect at the highest population. Bean biomass LER were increased significantly with each increment in bean population. Increases due to the first increment (B2) were similar at all $\mathrm{N}$ levels, but at B3 it also increased progressively as $\mathrm{N}$ levels were increased.

Similar to Russell \& Caldwell (1989) results, N applications increased significantly maize biomass LER; the range of increments was higher in all bean populations with the application of N2. At B3, the highest N level (N3) did not improve maize LER above that of N2. Effect of $\mathrm{N}$ on bean biomass LER was observed at B3, being significant at $\mathrm{N} 3$; this is an evidence that beans at $\mathrm{B} 3$ could benefit from the $\mathrm{N}$ applied to maize.

There was a consistent tendency of increasing total biomass LER with increases in bean populations and $\mathrm{N}$ levels, being significant from $\mathrm{B} 1$ to $\mathrm{B} 2$ and $\mathrm{N} 1$ to $\mathrm{N} 2$. The highest value at $\mathrm{B} 3-\mathrm{N} 3$ was 1.51 , i.e., a $51 \%$ yield increase compared to sole cropping. Maize was the main component for increasing total biomass LER at B1 and B2 due to increases in N levels. At B3, both

Table 1. Biomass, cob and pod yields and harvest index of maize and beans as sole and intercropping ${ }^{(1)}$.

\begin{tabular}{|c|c|c|c|c|c|c|c|c|c|c|c|c|c|c|c|c|c|c|}
\hline \multirow{3}{*}{$\begin{array}{l}\text { Cropping } \\
\text { system }\end{array}$} & \multicolumn{6}{|c|}{ Biomass vield $\left(\mathrm{kg} \mathrm{ha}^{-1}\right)$} & \multicolumn{6}{|c|}{ Yield $\left(\mathrm{kg} \mathrm{ha}^{-1}\right)$} & \multicolumn{6}{|c|}{ Harvest index (\%) } \\
\hline & \multicolumn{3}{|c|}{ Maize $^{(3)}$} & \multicolumn{3}{|c|}{ Beans ${ }^{(4)}$} & \multicolumn{3}{|c|}{$\mathrm{Cob}$ (maize) } & \multicolumn{3}{|c|}{ Pod $^{(5)}$ (beans) } & \multicolumn{3}{|c|}{ Maize } & \multicolumn{3}{|c|}{ Beans ${ }^{(6)}$} \\
\hline & $\mathrm{N} 1$ & $\mathrm{~N} 2$ & $\mathrm{~N} 3$ & $\mathrm{~N} 1$ & $\mathrm{~N} 2$ & $\mathrm{~N} 3$ & $\mathrm{~N} 1$ & $\mathrm{~N} 2$ & $\mathrm{~N} 3$ & $\mathrm{~N} 1$ & $\mathrm{~N} 2$ & $\mathrm{~N} 3$ & $\mathrm{~N} 1$ & $\mathrm{~N} 2$ & $\mathrm{~N} 3$ & $\mathrm{~N} 1$ & $\mathrm{~N} 2$ & $\mathrm{~N} 3$ \\
\hline Solecropping & 5,828 & 6,703 & 7,029 & 4,972 & & & 889 & 1,015 & 1,043 & 2,251 & & & 15.4 & 15.6 & 14.7 & 45.2 & & \\
\hline B1 & 3,777 & 5,567 & 6,035 & 1,620 & 1.599 & 1,690 & 661 & 1,086 & 955 & 686 & 622 & 670 & 17.3 & 19.8 & 15.4 & 42.4 & 39.0 & 39.7 \\
\hline B2 & 3,833 & 5,486 & 6,455 & 2,636 & 2.327 & 2,505 & 876 & 1,122 & 844 & 975 & 950 & 969 & 22.9 & 20.1 & 13.2 & 38.4 & 40.7 & 38.5 \\
\hline B3 & 3,155 & 4.867 & 5,019 & 3,207 & 3,477 & 3,936 & 523 & 860 & 740 & 1.212 & 1.401 & 1.594 & 16.9 & 17.4 & 14.4 & 37.8 & 40.2 & 40.5 \\
\hline
\end{tabular}

Table 2. Number and weight of cob per plant and weight per cob of maize, and dry matter and number of pods per plant and weight per pod of beans as sole and intercropping ${ }^{(1)}$.

\begin{tabular}{|c|c|c|c|c|c|c|c|c|c|c|c|c|c|c|c|c|c|c|}
\hline \multirow{3}{*}{$\begin{array}{l}\text { Cropping } \\
\text { system }^{(2)}\end{array}$} & \multicolumn{9}{|c|}{ Maize } & \multicolumn{9}{|c|}{ Beans } \\
\hline & \multicolumn{3}{|c|}{$\begin{array}{c}\text { Number of cob } \\
\text { per plant }\end{array}$} & \multicolumn{3}{|c|}{$\begin{array}{l}\text { Weight of cob } \\
\text { per plant }(\mathrm{g})\end{array}$} & \multicolumn{3}{|c|}{$\begin{array}{c}\text { Weight per cob } \\
(\mathrm{g})\end{array}$} & \multicolumn{3}{|c|}{$\begin{array}{c}\text { Dry matter per } \\
\text { plant }(\mathrm{g})\end{array}$} & \multicolumn{3}{|c|}{$\begin{array}{c}\text { Number of pod } \\
\text { per plant }\end{array}$} & \multicolumn{3}{|c|}{$\begin{array}{c}\text { Weight per pod } \\
(\mathrm{g})\end{array}$} \\
\hline & $\mathrm{N} 1$ & $\mathrm{~N} 2$ & $\mathrm{N3}$ & N1 & $\mathrm{N} 2$ & $\mathrm{N3}$ & $\mathrm{N} 1$ & $\mathrm{~N} 2$ & $\mathrm{N3}$ & $\mathrm{N} 1$ & $\mathrm{~N} 2$ & $\mathrm{N3}$ & $\mathrm{N1}$ & $\mathrm{N} 2$ & $\mathrm{N3}$ & $\mathrm{N} 1$ & $\mathrm{~N} 2$ & $\mathrm{N3}$ \\
\hline Solecropping & 1.32 & 1.55 & 1.65 & 5.4 & 18.5 & 18.9 & 11.7 & 11.8 & 11.0 & 20.5 & & & 7.1 & & & 1.30 & & \\
\hline B1 & 1.08 & 1.28 & 1.30 & 11.3 & 19.9 & 16.7 & 10.5 & 15.6 & 12.2 & 25.9 & 23.5 & 24.4 & 9.8 & 9.8 & 9.3 & 1.11 & 0.93 & 1.08 \\
\hline B2 & 0.90 & 1.50 & 1.37 & 15.3 & 21.8 & 15.8 & 17.2 & 14.3 & 11.6 & 14.5 & 16.6 & 16.7 & 6.7 & 6.5 & 6.2 & 1.01 & 1.02 & 1.03 \\
\hline B3 & 0.87 & 1.13 & 1.24 & 9.1 & 15.4 & 13.3 & 10.3 & 13.4 & 10.9 & 16.5 & 18.1 & 20.9 & 6.1 & 5.7 & 7.4 & 1.03 & 1.30 & 1.14 \\
\hline
\end{tabular}


component crops were increased by the application of N2, but contribution from maize component was a little higher. Only bean LER was increased at B3 with the application of N3, and was the main component for increasing total LER. The highest total biomass LER was obtained at B3 where bean LER was bigger

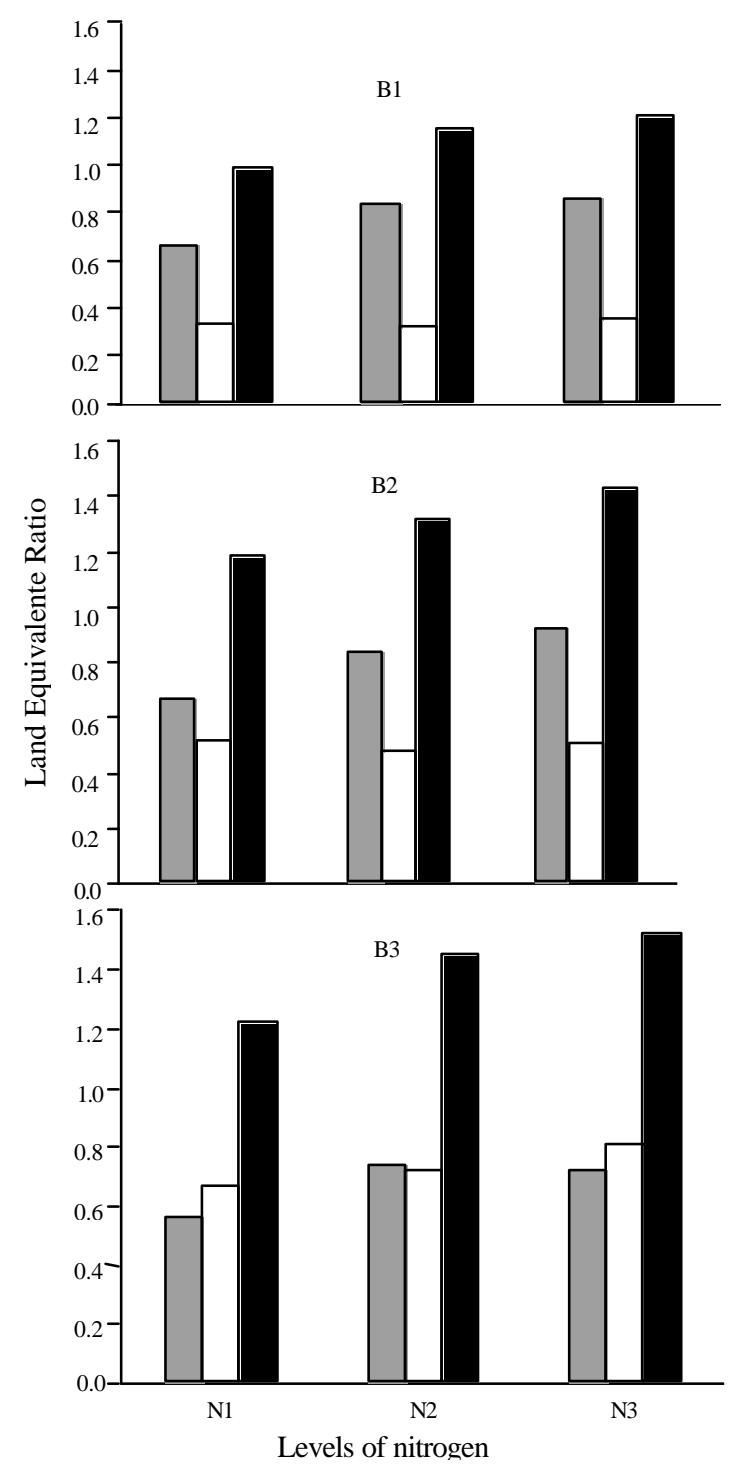

Figure 3. Land Equivalent Ratio for biomass yield of maize ( $\square$ ) and bean ( $\square$ ) intercrops and of total biomass $(\square)$. LSD for bean population: maize $=0.10$, beans $=0.13$, total $=0.15 ; \quad$ LSD for nitrogen level: maize $=0.15$, beans $=0.04$, total $=0.16$. or similar to maize LER, suggesting that decrease in component maize LER due to competitive effect of beans at high population was compensated by higher LER of beans.

Maize LER that increased at N1 and N2 with the first increment in bean population (B2) declined in all $\mathrm{N}$ levels at the highest population (B3) (Figure 4); they were significantly higher in $\mathrm{B} 2$ than in $\mathrm{B} 3$ at $\mathrm{N} 1$ and N2. This effect was also registered in component maize LER for biomass yield. Bean LER increased consistently and significantly with each increment in bean population at all $\mathrm{N}$ levels.

Nitrogen increased maize LER and this effect was highest in all bean populations at N2. Other studies showed similar effect of N (Baker \& Blamey, 1985; Aggarwal \& Sidhu, 1988; Siame et al., 1998). As in biomass LER for bean component, $\mathrm{N}$ did not have evident effect on bean LER for pod yields at B1 and B2, but at B3 they increased progressively with each increment in $\mathrm{N}$ levels.

There was a tendency for increasing total LER for cob and pod yields with increasing bean populations and $\mathrm{N}$ levels. A different tendency was observed in maize-cowpea intercropping (Ofori \& Stern, 1987). Bean population effect on total LER was significant at all $\mathrm{N}$ levels except at $\mathrm{N} 3$. Increasing $\mathrm{N}$ level from $\mathrm{N} 1$ to N2 brought about the highest total LER in all bean populations, and an advantage of $68 \%$ was obtained at B2, compared to sole cropping. Maize was the main component for increasing total LER due to $\mathrm{N}$ effect, however the differences between maize and bean contribution decreased at B3. This shows how bean competitive effect at B3 increased with $\mathrm{N}$ application.

No statistical evidence of $\mathrm{N}$ applied to maize rows affecting nodule number per plant at B1 (Table 3) was observed. There was a tendency for decreasing nodule number at B2 from 82 DAS and B3 from 62 DAS onwards with $\mathrm{N}$ applications, considered as an inhibition effect of $\mathrm{N}$ due to the nearness of bean plants to maize rows at B2 and B3 (Boller \& Nosberger, 1987). Means over N levels show that nodule number that was very low at early stages of plant growth increased to a maximum at 82 DAS than decreased at 92 DAS and increased again at 
107 DAS. There was a tendency for increasing nodule number with increasing bean populations. The greater competition of maize for soil available $\mathrm{N}$ at high bean populations, when bean plants were nearer to maize rows, might have stimulated root nodulation of intercropped beans (Abaidoo \& Kessel, 1989).
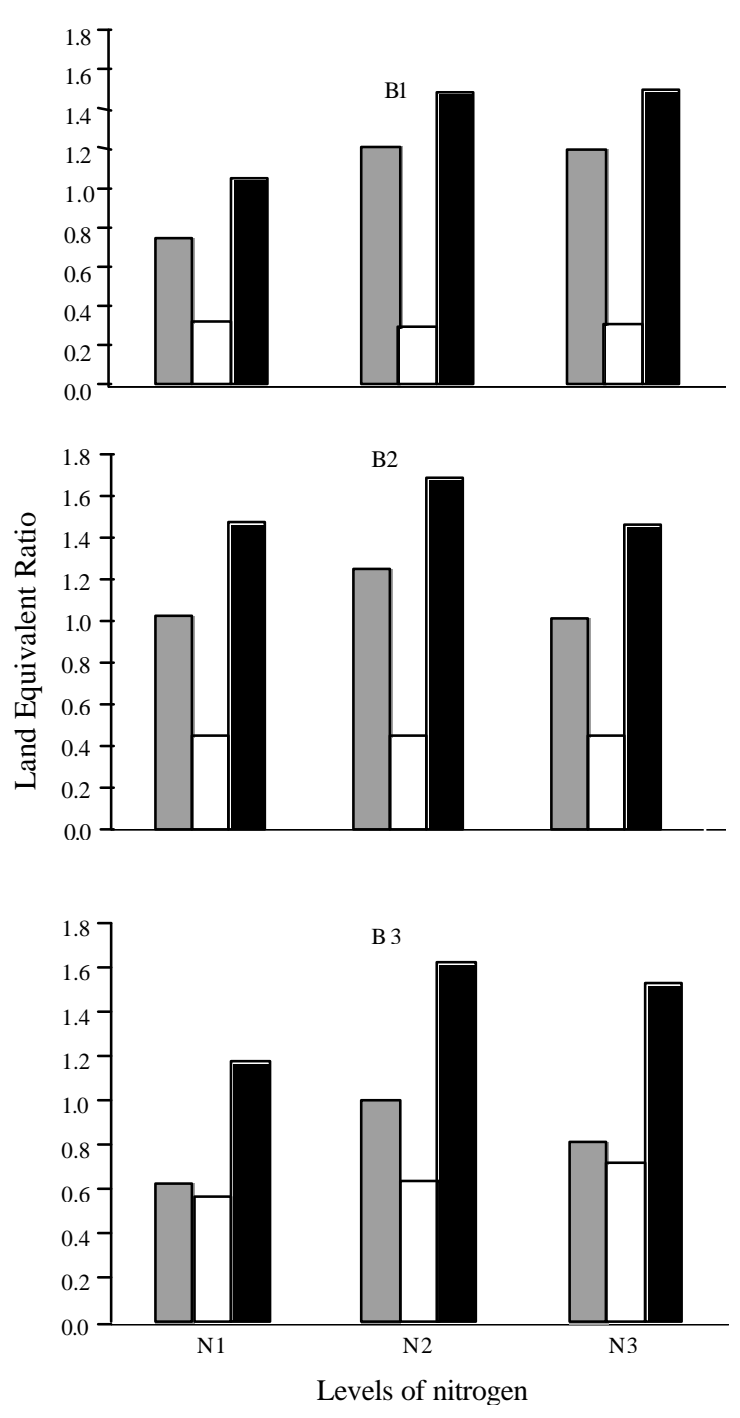

Figure 4. Land Equivalent Ratio for cob and pod yields of maize ( $\square$ ) and bean ( $\square$ intercrops, respectively and of total biomass ( $\square$. LSD for bean population: maize $=0.22$; beans $=0.15$; total $=0.12$. LSD for interaction: beans $=0.11$.
Table 3. Number of nodules per plant of intercropped beans ${ }^{(1)}$.

\begin{tabular}{|c|c|c|c|c|}
\hline $\begin{array}{c}\text { Days after } \\
\text { sowing }\end{array}$ & N1 & $\mathrm{N} 2$ & N3 & Mean \\
\hline & \multicolumn{4}{|c|}{60,000 plants ha $^{-1}$} \\
\hline 48 & 20.2 & 5.6 & 11.0 & 12.3 \\
\hline 62 & 48.5 & 20.8 & 37.0 & 35.4 \\
\hline 82 & 67.1 & 44.7 & 71.2 & 61.0 \\
\hline 92 & 40.6 & 62.6 & 25.3 & 42.8 \\
\hline 107 & 67.3 & 88.0 & 52.5 & 69.3 \\
\hline Mean & 48.7 & 44.3 & 39.4 & \\
\hline \multicolumn{5}{|c|}{120,000 plants ha $^{-1}$} \\
\hline 48 & 9.0 & 29.5 & 13.6 & 17.4 \\
\hline 62 & 22.6 & 12.0 & 34.8 & 23.1 \\
\hline 82 & 88.3 & 85.8 & 51.6 & 75.2 \\
\hline 92 & 106.1 & 52.5 & 47.0 & 68.5 \\
\hline 107 & 1496 & 113.7 & 64.3 & 109.2 \\
\hline Mean & 75.1 & 58.7 & 42.2 & \\
\hline \multicolumn{5}{|c|}{180,000 plants ha ${ }^{-1}$} \\
\hline 48 & 50.0 & 5.1 & 9.3 & 21.5 \\
\hline 62 & 40.3 & 29.3 & 17.1 & 28.9 \\
\hline 82 & 104.7 & 106.0 & 44.1 & 84.9 \\
\hline 92 & 66.3 & 58.5 & 46.8 & 57.2 \\
\hline 107 & 134.5 & 106.7 & 75.1 & 105.4 \\
\hline Mean & 79.2 & 61.1 & 38.5 & \\
\hline
\end{tabular}

\section{Conclusions}

1. Dry matter yield accumulation of individual maize plant decreases with increases in bean plant population and competitive effect is biggest at the highest level in an arrangement of one row of maize for three rows of beans.

2. Nitrogen fertilizer reduces competitive effect of intercropping on maize yields and application of $50 \mathrm{~kg} \mathrm{ha}^{-1} \mathrm{~N}$ is very efficient in increasing cob yield, as compared with unfertilized condition.

3 . The efficiency of intercropping, compared to sole cropping, is evidenced by the LER for biomass, cob and pod yields.

\section{References}

ABAIDOO, R. C.; KESSEL, C. van. ${ }^{15} \mathrm{~N}$ uptake, $\mathrm{N}_{2}$-fixation and rhizobial interstrain competition in soybean and bean, intercropped with maize. Soil Biology and Biochemistry, Oxford, v. 21, n. 1, p. 155-159, 1989.

ADIKU, S. G. K.; OZIER-LAFONTAINE, H.; BAJAZET, T. Patterns of root growth and water uptake of a maize-cowpea mixture grown under greenhouse conditions. Plant and Soil, Dordrecht, v. 235, n. 1, p. 8594, 2001 
AGGARWAL, G. C.; SIDHU, A. S. Effect of irrigation on maize-cowpea fodder intercropping at Ludhiana, India: advantages and intercrop competition. Field Crops Research, Amsterdam, v. 18, p. 177-184, 1988.

BAKER, C. M.; BLAMEY, F. P. C. Nitrogen fertilizer effects on yield and nitrogen uptake of sorghum and soybean, grown in sole cropping and intercropping systems. Field Crops Research, Amsterdam, v. 12, p. 233-240, 1985.

BOLLER, B. C.; NOSBERGER, J. Symbiotically fixed nitrogen from field-grown white clover and red clover mixed with ryegrasses at low level of ${ }^{15} \mathrm{~N}$ fertilization. Plant and Soil, Dordrecht, v. 104, n. 2, p. 219-226, 1987.

BONETTI, R. Transferência de nitrogênio do feijão para o milho consorciado: avaliação pelo método de diluição isotópica do ${ }^{15} \mathrm{~N}$ e efeito da associação micorrízica. 1991. 63 f. Tese (Doutorado em Agronomia) - Escola Superior de Agricultura Luiz de Queiroz, Piracicaba, 1991.

BROPHY, L. S.; HEICHEL, G. H.; RUSSELLE, M. P. Nitrogen transfer from forage legumes to grass in a systematic design. Crop Science, Madison, v. 27, n. 4, p. 753-758, 1987.

EAGLESHAM, A. R. J.; AYANABA, A.; RAO, V. R.; ESKEW, D. L. Improving the nitrogen nutrition of maize by intercropping with cowpea. Soil Biology and Biochemistry, Oxford, v. 13, p. 169-171, 1981.

NATARAJAN, M.; WILLEY, R. W. Sorghum-pigeonpea intercropping and the effects of plant population density - 2: resource use. Journal of Agricultural Science, Cambridge, England, v. 95, p. 59-65, 1980.

OFORI, F.; STERN, W. R. The combined effects of nitrogen fertilizer and density of the legume component on production efficiency in a maize/cowpea intercrop system. Field Crops Research, Amsterdam, v. 16, p. 4352, 1987.

OFORI, F.; STERN, W. R. Maize/cowpea intercrop system: effect of nitrogen fertilizer on productivity and efficiency. Field Crops Research, Amsterdam, v. 14, p. 247-261, 1986.

OLJACA, S.; CVETKOVIC, R.; KOVACEVIC, D.; VASIC, G.; MOMIROVIC, N. Effect of plant arrangement and irrigation on efficiency of maize (Zea mays) and bean (Phaseolus vulgaris) intercropping system. Journal of Agricultural Science, Cambridge, England, v. 135, p. 261-270, 2000.

PILBEAM, C. J.; WOOD, M.; MUGANE, P. G. Nitrogen use in maize-grain legume cropping systems in semi-arid Kenya. Biology and Fertility of Soils, Berlin, v. 20, p. 57-62, 1995.

RUSSELL, J. T.; CALDWELL, R. M. Effect of component densities and nitrogen fertilization on efficiency and yield of maize/soyabean intercrop. Experimental Agriculture, Cambridge, England, v. 25, p. 529-540, 1989.

SAITO, S. M. T. The nitrogen relationships of maize/bean associations. In: GRAHAM, P. H.; HARRIS, S. C. (Ed.). Biological nitrogen fixation. Cali: Centro Internacional de Agricultura Tropical, 1982. p. 631-639.

SEARLE, P. G. E.; COMUDOM, S.; SHEDDEN, D. C.; NANCE, R. A. Effect of maize + legume intercropping systems and fertilizer nitrogen on crop yields and residual nitrogen. Field Crops Research, Amsterdam, v. 4, p. 133 145, 1981.

SENARATNE, R.; LIYANAGE, N. D. L.; SOPER, R. J. Nitrogen fixation and $\mathrm{N}$ transfer from cowpea, mungbean and groundnut when intercropped with maize. Fertilizer Research, Dordrecht, v. 40, p. 41-48, 1995.

SIAME, J.; WILLEY, R. W.; MORSE, S. The response of maize Phaseolus intercropping to applied nitrogen on Oxisol in northern Zambia. Field Crops Research, Amsterdam, v. 55, p. 73-81, 1998.

SIAME, J.; WILLEY, R. W.; MORSE, S. A study of the partitioning of applied nitrogen between maize and beans in intercropping. Experimental Agriculture, Cambridge, England, v. 33, p. 35-41, 1997.

TRENBATH, B. R. Plant interaction in mixed crop communities. In: PAPENDICK, R. I.; SANCHES, P. A.; TRIPLETT, G. B. (Ed.). Multiple cropping. Madison: American Society of Agronomy, 1976. p. 129-169. (Special Publication, 27).

WILLEY, R. W. Evaluation and presentation of intercropping advantages. Experimental Agriculture, Cambridge, England, v. 21, n. 2, p. 119-133, 1985. 